\title{
Strategi Pengembangan Potensi Pariwisata di Pantai Kuri Caddi Desa Nisombalia, Kabupaten Maros
}

\section{Development Strategy on Tourism Potential of Kuri Caddi Beach, Nisombalia Village, Maros Regency}

\author{
Farah Alivia Yunita Laoh ${ }^{1}$, Agus Salim ${ }^{1,2}$, Rusneni Ruslan ${ }^{1}$ \\ ${ }^{1}$ Program Studi Perencanaan Wilayah dan Kota, Fakultas Teknik, Universitas Bosowa \\ ${ }^{2}$ Program Studi Pascasarjana Perencanaan Wilayah dan Kota, Fakultas Teknik, Universitas Bosowa \\ Email : Farahyunita1999@gmail.com
}

\section{Artikel info}

\section{Artikel history:}

Diterima; 21-03-2021

Direvisi: 25-03-2021

Disetujui;30-03-2021
Abstract. This study aimed to identify what factors affecting the development of tourism in Kuri Caddi Beach, Nisombalia Village, Maros Regency. As well as to identify a strategy for developing tourism potential on Kuri Caddi Beach, Nisombalia Village, Maros Regency. The variables used consisted : (1) Tourist Attraction; (2) Supporting Facilities; (3) Safety and Comfort; (4) Information and Promotion; (5) Accessibility; (6) Job Opportunities; (7) (Income). The analytical method used chi-square, likert scale scoring, and SWOT analysis. There were four variables that have effect on the tourism potential development strategy in Kuri Caddi Beach, which are tourist attraction, safety and comfort, job opportunities and income. Meanwhile, there were three variables that have no effect, such us supporting facilities, information and promotion, and accessibility. The strategy that can be used for developing tourism potential on Kuri Caddi Beach is by utilizing the tourist attraction of Kuri Caddi Beach by referring to the Maros Regency Regional Regulation number 2 of 2014, concerning the implementation of tourism, involving the community in developing Kuri Caddi Beach tourism based on the Regional Tourism Development Master Plan, and involves investors in developing Kuri Caddi Beach tourism, so that PAD and local community income are increased.

\begin{abstract}
Abstrak. Tujuan dari penelitian ini adalah untuk mengidentifikasi faktor apa saja yang mempengaruhi pengembangan pariwisata di Pantai Kuri Caddi Desa Nisombalia Kabupaten Maros. Serta untuk mengidentifikasi strategi pengembangan potensi pariwisata di Pantai Kuri Caddi Desa Nisombalia Kabupaten Maros. Variabel yang digunakan terdiri dari tujuh diantaranya: (1) Daya Tarik Wisata; (2) Sarana Penunjang; (3) Keamanan dan Kenyamanan; (4) Informasi dan Promosi; (5) Aksesibilitas; (6) Peluang Kerja; (7) (Pendapatan). Metode analisis yang digunakan berupa chi-square, sistem skoring Skala Likert dan analisis SWOT. Variabel yang memiliki pengaruh terhadap strategi pengembangan potensi pariwisata di Pantai Kuri Caddi ada empat variabel yaitu daya tarik wisata, keamanan dan kenyamanan, peluang kerja dan pendapatan. Sedangkan variabel yang tidak memiliki pengaruh ada tiga yaitu sarana penunjang, informasi dan promosi, serta aksesibilitas. Sehingga strategi yang dapat digunakan dalam strategi pengembangan potensi pariwisata di Pantai Kuri Caddi Desa Nisombalia Kabupaten Maros yaitu dengan memanfaatkan daya tarik wisata Pantai Kuri Caddi dengan mengacu pada pada Perda Kabupaten Maros nomor 2 Tahun 2014, tentang penyelenggaraan kepariwisataan, melibatkan masyarakat dalam mengembangkan wisata Pantai Kuri Caddi berdasarkan Rencana Induk Pengembangan Kepariwisataan Daerah, serta melibatkan investor dalam
\end{abstract}




\section{Keywords:}

Beach Developing;

Tourism;

Strategy. mengembangkan wisata Pantai Kuri Caddi, sehingga dapat meningkatkan PAD dan pendapatan masyarakat lokal..

Coresponden author:

Email: Farahyunita1999@gmail.com

artikel dengan akses terbuka dibawah lisensi CC BY -4.0

\section{PENDAHULUAN}

Pariwisata telah menjadi sektor utama pengembangan di negara-negara di dunia, termasuk Indonesia. Indonesia menjadi salah satu negara yang saat ini berkomitmen untuk mengembangkan pariwisata dengan mendorong destinasi-destinasi di Indonesia untuk mengelola dan mempromosikan potensi pariwisata. Potensipotensi yang ada yang dimiliki setiap daerah baik berupa alam, budaya maupun buatan didorong untuk memberikan nilai manfaat ke masyarakat. Pemerintah juga mendorong pembangunan infrastruktur untuk mendukung pengembangan pariwisata di setiap wilayah di Indonesia. Karena itu, daerah-daerah di Indonesia telah memiliki potensi wisata unggulan yang dijadikan sebagai penarik bagi wisatawan untuk datang dan berkunjung ke destinasi wisata. Pariwisata di Indonesia merupakan sektor ekonomi penting di Indonesia. Pada tahun 2009, pariwisata menempati urutan ketiga dalam hal penerimaan devisa setelah komoditas minyak dan gas bumi serta minyak kelapa sawit. Berdasarkan data tahun 2016, jumlah wisatawan mancanegara yang datang ke Indonesia sebesar 11.525.963 juta lebih atau tumbuh sebesar 10,79\% dibandingkan tahun sebelumnya. Pembangunan ekonomi merupakan suatu proses yang terjadi dalam jangka panjang dan bertujuan untuk meningkatkan kualitas kehidupan semua orang (Ritonga, 2005). Kekayaan alam dan budaya merupakan komponen penting dalam pariwisata di Indonesia. Alam Indonesia memiliki kombinasi iklim tropis, 17.508 pulau yang 6.000 di antaranya tidak dihuni, serta garis pantai terpanjang ketiga di dunia setelah Kanada dan Uni Eropa. Indonesia juga merupakan negara kepulauan terbesar dan berpenduduk terbanyak di dunia.

Wilayah Kabupaten Maros merupakan salah satu Kabupaten tempat tujuan wisata di Provinsi Sulawesi Selatan. Di antara destinasi wisata alam yang memiliki potensi wisata bahari di Maros, yakni Pantai Kuri. Pantai yang terletak di Dusun Kuri Caddi Desa Nisombalia Kecamatan Marusu ini memiliki keindahan panorama alam yang menakjubkan. Di pantai tersebut, bentangan batu karang berjejer dengan indah, dilengkapi bukit batu. Pasir putih dan tanaman mangrove menambah keindahan saat pengunjung menikmati suasana matahari terbenam atau sunset. Wisatawan juga bisa menyusuri lorong-lorong mangrove dengan menyewa perahu pelayan. Adanya pariwisata Pantai Kuri Caddi akan memberikan dampak positif baik dari sisi lingkungan maupun dari sisi ekonomi, seperti yang tertera pada RTRW Kabupaten Maros bahwa kawasan wisata Pantai Kuri Caddi masuk dalam kawasan peruntukan wisata alam dan juga sebagai kawasan strategis Kabupaten Maros dalam sudut kepentingan pertumbuhan ekonomi. Apabila pariwisata Pantai Kuri Caddi dikelola dengan baik maka akan sangat berdampak positif pada lingkungan di sekitar pesisir di Kabupaten Maros dan akan menguntungkan ekonomi bagi masyarakat setempat, atau masyarakat lokal.

Berdasarkan pernyataan di atas, maka kawasan wisata pantai Kuri Caddi telah sering dijadikan tempat wisata oleh masyarakat setempat pada waktu liburan. Namun penataan kawasannya belum tertata baik sehingga masih membutuhkan sentuhan. Namun, masih terdapat beberapa permasalahan yang ada di Pantai Kuri Caddi. Masalah yang terdapat di Pantai Kuri Caddi yaitu tidak mudah memasuki dusun Kuri Caddi, diperlukan keseimbangan dan kondisi kendaraan yang prima karena jalan bebatuan tajam yang bergelombang dan berkelok ini, hanya bisa dilewati satu mobil saja, belum lagi jembatan kayu yang jika dilewati harus ekstra hati-hati. Akses jalan yang akan di tempuh jika ke lokasi Pantai Kuri akan memakan waktu 45 menit sampai dengan 1 jam lamanya karena kondisi jalan yang belum memadai dan perlu adanya pembenahan. Oleh karena itu, diperlukan strategi-strategi yang efektif dalam mengembangkan potensi pariwisata Pantai Kuri Caddi, agar nantinya dapat menjadi salah satu potensi destinasi pariwisata terbaik di Kabupaten Maros yang dapat di andalkan dan diminati untuk dikunjungi oleh masyarakat Maros maupun masyarakat pendatang dari luar. Berdasarkan alasan di atas, maka penelitian ini bertujuan untuk mengidentifikasi faktor apa saja yang mempengaruhi pengembangan pariwisata di Pantai Kuri Caddi Desa Nisombalia Kabupaten Maros serta mengidentifikasi strategi pengembangan potensi pariwisata di Pantai Kuri Caddi Desa Nisombalia Kabupaten Maros.

\section{METODE}

\subsection{Lokasi Penelitian}

Lokasi Penelitian berada pada Pantai Kuri Caddi yang berada pada wilayah administrasi Kabupaten Maros, tepatnya di Kecamatan Marusu, Desa Nisombalia (Gambar 1). 


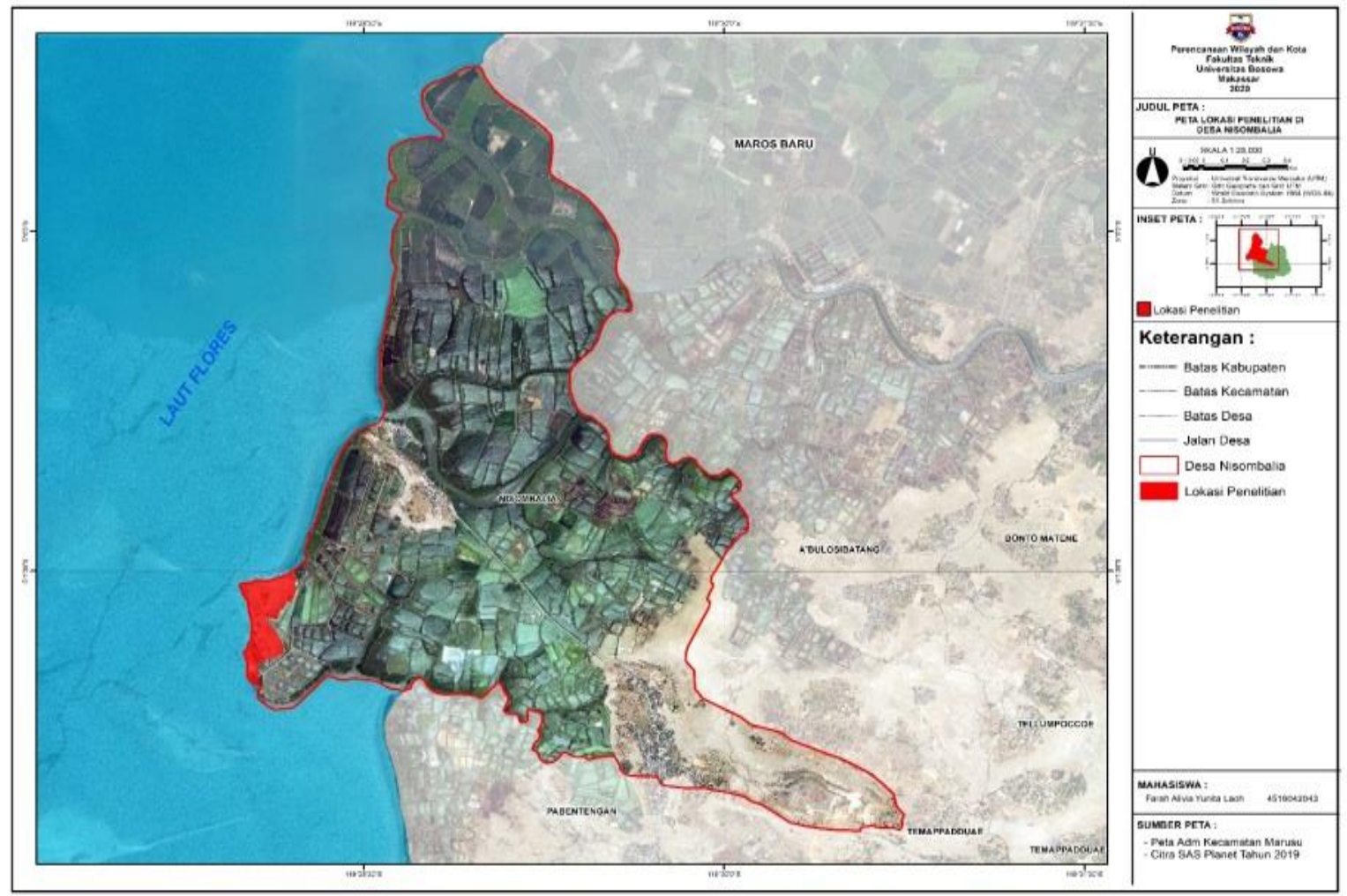

Gambar 1. Peta Pantai Kuri Caddi.

\subsection{Variabel Penelitian}

Variabel/indikator yang digunakan dalam penelitian ini akan dikaji dan dianalisis pengaruhnya terhadap Pengembangan Potensi Pariwisata di Pantai Kuri Caddi didasarkan pada teori menurut Suwantoro (2003), dan menurut Dian Widya Setiyanti (2011) diantaranya :

Tabel 1. Variabel Peneltian

\begin{tabular}{|c|c|}
\hline Variabel & Indikator \\
\hline $\mathrm{Y}=$ Pengembangan Pariwisata & $\begin{array}{l}\text { - Sudah ada Pengembangan } \\
\text { - } \quad \text { Belum ada Pengembangan }\end{array}$ \\
\hline X1 = Daya Tarik Wisata & $\begin{array}{ll}\text { - } & \text { Wisata Bahari } \\
\text { - } & \text { Atraksi Budaya } \\
\text { - } & \text { View } \\
\text { - } & \text { Wisata Minat Khusus }\end{array}$ \\
\hline $\mathrm{X} 2$ = Sarana Penunjang Wisata & $\begin{array}{ll}\text { - } & \text { Lahan Parkir } \\
\text { - } & \text { Fasilitas Peribadatan } \\
\text { - } & \text { Fasilitas Persampahan } \\
\text { - } & \text { Fasilitas Perdagangan } \\
\end{array}$ \\
\hline X3 = Keamanan dan Kenyamanan & $\begin{array}{l}\text { - Petugas Khusus Keamanan } \\
\text { - Pengawas Pantai } \\
\text { - Petugas Kebersihan } \\
\text { - Pelayanan Pengelolaan } \\
\text { - Tingkat Kebersihan } \\
\text { - Kenyamanan } \\
\end{array}$ \\
\hline $\mathrm{X} 4$ = Informasi dan Promosi & $\begin{array}{l}\text { - } \text { Media Promosi } \\
\text { - Ketersediaan Informasi } \\
\text { - Sumber Informasi } \\
\text { - Jaringan Telekomunikasi }\end{array}$ \\
\hline X5 = Aksesibilitas & - Jaringan Jalan \\
\hline X6 = Peluang Kerja & - Tersedia \\
\hline
\end{tabular}




\begin{tabular}{lll}
\hline & Variabel & \multicolumn{1}{c}{ Indikator } \\
\hline & $\bullet$ & Tidak Tersedia \\
\hline \multirow{2}{*}{7 = Pendapatan } & $\bullet$ Adanya Pengaruh \\
& $\bullet$ Tidak Adanya Pengaruh \\
\hline
\end{tabular}

\subsection{Teknik Pengumpulan Data}

Pengumpulan data pada penelitian ini menggunakan beberapa metode:

a. Pendataan instasional yaitu mengumpulkan data melalui instansi terkait guna mengetahui data kualitatif dan kuantitatif lokasi penelitian.

b. Metode angket (kuesioner), menggunakan kuesioner tertutup.

c. Wawancara merupakan teknik pengumpulan data yang dilakukan secara langsung melalui tatap muka dan tanya jawab langsung antara peneliti dan narasumber

d. Survey lapangan, dilakukan untuk mendapatkan data yang lebih mendetail, aktual dan langsung untuk mendapatkan data primer dari objek penelitian.

e. Peneliti mempelajari data, baik data kualitatif maupun kuantitatif melalui sumber dokumen (laporan, jurnal, internet, monografi daerah, buku-buku, dan lainnya.

f. Dokumentasi merupakan suatu proses pengumpulan data dengan melakukan dokumentasi yang relevan dengan penelitian ini

\subsection{Teknik Analisis Data}

Teknik analisis data pada penelitian ini sebagai berikut:

a. Analisis Chi-square

Chi-square juga disebut sebagai Kai Kuadrat merupakan salah satu jenis uji komparatif non parametris yang dilakukan pada dua variabel dengan skala data kedua variabel ada nominal. Adapun rumus dari analisis chi-square ialah :

$$
X^{2}=\frac{\left(F_{o}-F_{h}\right)^{2}}{\left(F_{h}\right)}
$$

Keterangan :

$\mathrm{X}^{2}=$ Nilai Chi-Square

$\mathrm{F}_{\mathrm{h}}=$ Frekuensi yang diharapkan

$\mathrm{F}_{0}=$ Frekuensi yang diperoleh/diamati

Untuk mengetahui frekuensi yang diharapkan (Fn) pada masing-masing frekuensi menurut baris dan kolom, jumlah masing-masing sub bagian dan jumlah keseluruhan. Selanjutnya dapat dimasukkan ke dalam rumus sebagai berikut:

$$
F_{h}=\frac{\left(n_{f b}-n_{f k}\right)^{2}}{N}
$$

Keterangan:

$\mathrm{F}_{\mathrm{h}}=$ Frekuensi yang diharapkan

$\mathrm{n}_{\mathrm{fb}}=$ Jumlah frekuensi masing-masing baris

$\mathrm{n}_{\mathrm{fk}}=$ Jumlah frekuensi masing-masing kolom

b. Skala Likert

Skala likert digunakan untuk mengetahui hubungan antara variabel $\mathrm{X}$ dan $\mathrm{Y}$ dengan patokan interpresentase nilai. Dalam penelitian ini, hasil analisis uji chi-square akan dicocokkan dengan sistem skoring dalam skala likert untuk menentukan korelasi variabel dengan tingkat pengaruhnya terhadap partisipasi masyarakat

Tabel 2. Penentuan Skala Likert

\begin{tabular}{|l|l|}
\hline \multicolumn{1}{|c|}{ Nilai } & \multicolumn{1}{|c|}{ Pengaruh } \\
\hline $0,80-1,00$ & Pengaruh sangat kuat \\
$0,60-0,79$ & Pengaruh kuat \\
$0,40-0,59$ & Pengaruh sedang \\
$0,20-0,39$ & Pengaruh lemah \\
$0,00-0,19$ & Pengaruh sangat lemah \\
\hline
\end{tabular}

Sumber: Maria M.I (2000) 
c. Analisis SWOT

Analisisi SWOT merupakan suatu teknik perencanaan strategi yang bermanfaat untuk mengevaluasi kekuatan (strength), kelemahan (weakness), peluang (opportunities) dan ancaman (threats) dalam suatu proyek ataupun penelitian, baik yang sementara berlangsung maupun dalam perencanaan baru. Dari analisis SWOT akan muncul strategi-strategi sebagai upaya dalam mengembangkan suatu kawasan.

\section{HASIL DAN PEMBAHASAN}

\subsection{Analisis Faktor Yang Mempengaruhi Pengembangan Potensi Pariwisata Pantai Kuri Caddi}

\subsubsection{Pengaruh Daya Tarik Wisata (X1) Terhadap Pengembangan Potensi Pariwisata Pantai Kuri Caddi}

Tabel 3. Pengaruh Daya Tarik Wisata (X1) Terhadap Pengembangan Potensi Pariwisata Pantai Kuri Caddi

\begin{tabular}{|c|c|c|c|c|c|c|c|c|c|}
\hline \multirow{2}{*}{$\mathrm{Y}$} & \multirow[t]{2}{*}{$\mathrm{X}$} & \multicolumn{2}{|c|}{$\mathbf{X}$} & \multirow[t]{2}{*}{$\sum$} & \multicolumn{2}{|c|}{ FH } & \multicolumn{2}{|c|}{$\mathbf{X}^{2}$} & \multirow[t]{2}{*}{$\sum$} \\
\hline & & 1 & 2 & & 1 & 2 & 1 & 2 & \\
\hline \multirow{2}{*}{$\mathrm{Y}$} & 1 & 67 & 7 & 74 & 62.9 & 11.1 & 0.27 & 1.51 & 1.78 \\
\hline & 2 & 18 & 8 & 26 & 22.1 & 3.9 & 0.76 & 4.31 & 5.07 \\
\hline$\sum$ & & 85 & 15 & 100 & & & & & \\
\hline$x^{2}$ & & & & & & & & & 6.85 \\
\hline $\mathrm{db}$ & & & & & & & & & 1.00 \\
\hline $\mathrm{X}^{2}$ Tabel & & & & & & & & & 3.84 \\
\hline Kesimpulan & & & & & & & & rpeng & \\
\hline
\end{tabular}

Sumber: Hasil Analisis, Tahun 2020

Berdasarkan Tabel 3 dapat dilihat bahwa persepsi dalam pengembangan pariwisata di Pantai Kuri Caddi menurut uji chi kuadrat berpengaruh terhadap aspek Daya Tarik Wisata. Maka selanjutnya dilakukan uji kontingensi dimana :

$$
\begin{aligned}
C & =\sqrt{\left.\frac{X^{2}}{\left(N+X^{2}\right)}\right)} \\
C & =\sqrt{\left.\frac{6.85}{(100+6.85)}\right)} \\
& =0,24 \text { (Pengaruh Lemah) }
\end{aligned}
$$

\subsubsection{Pengaruh Sarana Penunjang Wisata (X2) Terhadap Pengembangan Potensi Pariwisata Pantai Kuri Caddi}

\begin{tabular}{|c|c|c|c|c|c|c|c|c|c|}
\hline \multirow[b]{2}{*}{ Y } & \multirow[t]{2}{*}{$\mathrm{X}$} & \multicolumn{2}{|l|}{$\mathbf{X}$} & \multirow[t]{2}{*}{$\sum$} & \multicolumn{2}{|l|}{ FH } & \multicolumn{2}{|l|}{$\mathbf{X}^{2}$} & \multirow[t]{2}{*}{$\sum$} \\
\hline & & 1 & 2 & & 1 & 2 & 1 & 2 & \\
\hline $\mathrm{Y}$ & 1 & 58 & 16 & 74 & 56.98 & 17.02 & 0.02 & 0.06 & 0.08 \\
\hline 1 & 2 & 19 & 7 & 26 & 20.02 & 5.98 & 0.05 & 0.17 & 0.23 \\
\hline$\sum$ & & 77 & 23 & 100 & & & & & \\
\hline $\mathrm{x}^{2}$ & & & & & & & & & 0.31 \\
\hline $\mathrm{db}$ & & & & & & & & & 1.00 \\
\hline $\mathrm{X}^{2}$ Tabel & & & & & & & & & 3.84 \\
\hline
\end{tabular}

Tabel 4. Pengaruh Sarana Penunjang Wisata (X2) Terhadap Pengembangan Potensi Pariwisata Pantai Kuri Caddi

Sumber: Hasil Analisis, Tahun 2020

Tidak Berpengaruh

Berdasarkan Tabel 4 diatas, dapat dilihat bahwa persepsi dalam pengembangan pariwisata di Pantai Kuri Caddi menurut uji chi kuadrat tidak berpengaruh terhadap aspek Sarana Penunjang Wisata. Maka selanjutnya dilakukan uji kontingensi dimana:

$$
\begin{aligned}
& C=\sqrt{\left.\frac{X^{2}}{\left(N+X^{2}\right)}\right)} \\
& C=\sqrt{\left.\frac{0.31}{(100+0.31)}\right)}
\end{aligned}
$$


$=0,17$ (Pengaruh Sangat Lemah)

\subsubsection{Pengaruh Keamanan dan Kenyamanan (X3) Terhadap Pengembangan Potensi Pariwisata Pantai Kuri Caddi}

Tabel 5. Pengaruh Keamanan dan Kenyamanan (X3) Terhadap Pengembangan Potensi Pariwisata

\begin{tabular}{|c|c|c|c|c|c|c|c|c|c|}
\hline \multicolumn{10}{|c|}{ Pantai Kuri Caddi } \\
\hline \multirow{2}{*}{$\begin{array}{l}\mathrm{X} \\
\mathrm{Y}\end{array}$} & \multicolumn{3}{|c|}{$\mathbf{X}$} & \multirow[t]{2}{*}{$\sum$} & \multicolumn{2}{|l|}{ FH } & \multicolumn{2}{|l|}{$\mathbf{X}^{2}$} & \multirow[t]{2}{*}{$\Sigma$} \\
\hline & & 1 & 2 & & 1 & 2 & 1 & 2 & \\
\hline \multirow{2}{*}{$\mathrm{Y}$} & 1 & 72 & 2 & 74 & 68.08 & 5.92 & 0.23 & 2.60 & 2.82 \\
\hline & 2 & 20 & 6 & 26 & 23.92 & 2.08 & 0.64 & 7.39 & 8.03 \\
\hline$\sum$ & & 92 & 8 & 100 & & & & & \\
\hline $\mathrm{x}^{2}$ & & & & & & & & & 10.85 \\
\hline $\mathrm{db}$ & & & & & & & & & 1.00 \\
\hline $\mathrm{X}^{2}$ Tabel & & & & & & & & & 3.84 \\
\hline
\end{tabular}

Sumber: Hasil Analisis, 2020

Berdasarkan Tabel 5 diatas, dapat dilihat bahwa persepsi dalam pengembangan pariwisata di Pantai Kuri Caddi menurut uji chi kuadrat berpengaruh terhadap aspek Keamanan dan Kenyamanan. Maka selanjutnya dilakukan uji kontingensi dimana:

$$
\begin{aligned}
\mathrm{C} & =\sqrt{\left.\frac{X^{2}}{\left(N+X^{2}\right)}\right)} \\
\mathrm{C} & =\sqrt{\left.\frac{0.85}{(100+0.85)}\right)} \\
& =0.31 \text { (Berpengaruh Lemah) }
\end{aligned}
$$

\subsubsection{Pengaruh Informasi dan Promosi Wisata (X4) Terhadap Pengembangan Potensi Pariwisata Pantai}

\begin{tabular}{|c|c|c|c|c|c|c|c|c|c|}
\hline & & $\mathbf{X}$ & & $\sum$ & FH & & $\mathbf{X}^{2}$ & & $\sum$ \\
\hline $\mathrm{Y}$ & & 1 & 2 & & 1 & 2 & 1 & 2 & \\
\hline \multirow{2}{*}{ Y } & 1 & 50 & 24 & 74 & 49.58 & 24.42 & 0.00 & 0.01 & 0.01 \\
\hline & 2 & 17 & 9 & 26 & 17.42 & 8.58 & 0.01 & 0.02 & 0.03 \\
\hline$\sum$ & & 67 & 33 & 100 & & & & & \\
\hline $\mathrm{x}^{2}$ & & & & & & & & & 0.04 \\
\hline $\mathrm{db}$ & & & & & & & & & 1.00 \\
\hline $\mathrm{X}^{2}$ Tabel & & & & & & & & & 3.84 \\
\hline
\end{tabular}
Kuri Caddi

Tabel 6. Uji Chi Kuadrat Sistem Pengelolaan Air Limbah Terhadap Kekumuhan

Kesimpulan $\quad$ Tidak Berpengaruh

Sumber: Hasil Analisis, Tahun 2020

Berdasarkan Tabel 6 diatas, dapat dilihat bahwa persepsi dalam pengembangan pariwisata di Pantai Kuri Caddi menurut uji chi kuadrat tidak berpengaruh terhadap aspek Informasi dan Promosi. Maka selanjutnya dilakukan uji kontingensi dimana:

$$
\begin{aligned}
& C=\sqrt{\left.\frac{X^{2}}{\left(N+X^{2}\right)}\right)} \\
& C=\sqrt{\left.\frac{0.04}{(100+0.04)}\right)}
\end{aligned}
$$

$=0.17$ (Berpengaruh Sangat Lemah 


\subsubsection{Pengaruh Aksesibilitas Wisata (X5) Terhadap Pengembangan Potensi Pariwisata Pantai Kuri Caddi}

Tabel 7. Pengaruh Aksesibilitas Wisata (X5) Terhadap Pengembangan Potensi Pariwisata Pantai Kuri Caddi

\begin{tabular}{|c|c|c|c|c|c|c|c|c|c|}
\hline & & $\mathbf{X}$ & & $\sum$ & FH & & $\mathbf{X}^{2}$ & & $\sum$ \\
\hline $\mathrm{Y}$ & & 1 & 2 & & 1 & 2 & 1 & 2 & \\
\hline \multirow{2}{*}{$\mathrm{Y}$} & 1 & 62 & 12 & 74 & 61.42 & 12.58 & 0.01 & 0.03 & 0.03 \\
\hline & 2 & 21 & 5 & 26 & 21.58 & 4.42 & 0.02 & 0.08 & 0.09 \\
\hline$\sum$ & & 83 & 17 & 100 & & & & & \\
\hline $\mathrm{x}^{2}$ & & & & & & & & & 0.12 \\
\hline $\mathrm{db}$ & & & & & & & & & 1.00 \\
\hline $\mathrm{X}^{2}$ Tabel & & & & & & & & & 3.84 \\
\hline
\end{tabular}

Kesimpulan Tidak Berpengaruh

Sumber: Hasil Analisis, Tahun 2020

Berdasarkan Tabel 7 dapat dilihat bahwa persepsi dalam pengembangan pariwisata di Pantai Kuri Caddi menurut uji chi kuadrat tidak berpengaruh terhadap aspek Aksesibilitas. Maka selanjutnya dilakukan uji kontingensi dimana:

$$
\begin{aligned}
\mathrm{C} & =\sqrt{\left.\frac{X^{2}}{\left(N+X^{2}\right)}\right)} \\
\mathrm{C} & =\sqrt{\left.\frac{0.12}{(100+0.12)}\right)} \\
& =0.17 \text { (Berpengaruh Sangat Lemah) }
\end{aligned}
$$

\begin{tabular}{|c|c|c|c|c|c|c|c|c|c|}
\hline \multicolumn{10}{|c|}{ Pantai Kuri Caddi } \\
\hline \multirow{2}{*}{$\begin{array}{l}X \\
Y\end{array}$} & & $\mathbf{X}$ & & $\sum$ & FH & & $\mathbf{X}^{2}$ & & $\sum$ \\
\hline & & 1 & 2 & & 1 & 2 & 1 & 2 & \\
\hline \multirow{2}{*}{ Y } & 1 & 68 & 6 & 74 & 62.9 & 11.1 & 0.41 & 2.34 & 2.76 \\
\hline & 2 & 17 & 9 & 26 & 22.1 & 3.9 & 1.18 & 6.67 & 7.85 \\
\hline$\sum$ & & 85 & 15 & 100 & & & & & \\
\hline$x^{2}$ & & & & & & & & & 10.60 \\
\hline $\mathrm{db}$ & & & & & & & & & 1.00 \\
\hline $\mathrm{X}^{2}$ Tabel & & & & & & & & & 3.84 \\
\hline
\end{tabular}

\subsubsection{Pengaruh Peluang Kerja (X6) Terhadap Pengembangan Potensi Pariwisata Pantai Kuri Caddi}

Tabel 8. Pengaruh Peluang Kerja (X6) Terhadap Pengembangan Potensi Pariwisata

\begin{tabular}{ll}
\hline Kesimpulan & Berpengaruh \\
\hline Sumber: Hasil Analisis, Tahun 2020 &
\end{tabular}

Berdasarkan Tabel 8 dapat dilihat bahwa Waktu Pengangkutan Sampah menurut uji chi kuadrat berpengaruh terhadap kekumuhan di Kelurahan Tallo. Untuk mengukur tingkat pengaruh waktu pengangkutan sampah terhadap kekumuhan di Kelurahan Tallo maka selanjutnya dilakukan uji kontingensi dim dapat dilihat bahwa persepsi dalam pengembangan pariwisata di Pantai Kuri Caddi menurut uji chi kuadrat berpengaruh terhadap aspek Peluang Kerja. Maka selanjutnya dilakukan uji kontingensi dimana :

$$
\begin{aligned}
C & =\sqrt{\left.\frac{X^{2}}{\left(N+X^{2}\right)}\right)} \\
C & =\sqrt{\left.\frac{10.6}{(100+10.6)}\right)} \\
& =0,31 \text { (Berpengaruh Lemah) }
\end{aligned}
$$




\subsubsection{Pengaruh Pendapatan (X7) Terhadap Pengembangan Potensi Pariwisata Pantai Kuri Caddi}

Tabel 9. Pengaruh Pendapatan (X7) Terhadap Pengembangan Potensi Pariwisata Pantai Kuri Caddi

\begin{tabular}{|c|c|c|c|c|c|c|c|c|c|}
\hline & & $\mathbf{X}$ & & $\sum$ & FH & & $\mathrm{X}^{2}$ & & $\sum$ \\
\hline $\mathrm{Y}$ & & 1 & 2 & & 1 & 2 & 1 & 2 & \\
\hline \multirow{2}{*}{ Y } & 1 & 66 & 8 & 74 & 59.2 & 14.8 & 0.78 & 3.12 & 3.91 \\
\hline & 2 & 14 & 12 & 26 & 20.8 & 5.2 & 2.22 & 8.89 & 11.12 \\
\hline$\sum$ & & 80 & 20 & 100 & & & & & \\
\hline$x^{2}$ & & & & & & & & & 15.02 \\
\hline $\mathrm{db}$ & & & & & & & & & 1.00 \\
\hline $\mathrm{X}^{2}$ Tabel & & & & & & & & & 3.84 \\
\hline
\end{tabular}

Kesimpulan

Berdasarkan Tabel 9 dapat dilihat bahwa Waktu Pengangkutan Sampah menurut uji chi kuadrat berpengaruh terhadap kekumuhan di Kelurahan Tallo. Untuk mengukur tingkat pengaruh waktu pengangkutan sampah terhadap kekumuhan di Kelurahan Tallo maka selanjutnya dilakukan uji kontingensi dim dapat dilihat bahwa persepsi dalam pengembangan pariwisata di Pantai Kuri Caddi menurut uji chi kuadrat berpengaruh terhadap aspek Pendapatan. Maka selanjutnya dilakukan uji kontingensi dimana :

$$
\begin{aligned}
C & =\sqrt{\left.\frac{X^{2}}{\left(N+X^{2}\right)}\right)} \\
C & =\sqrt{\left.\frac{15.02}{(100+15.02)}\right)} \\
& =0,36 \text { (Berpengaruh Lemah) }
\end{aligned}
$$

\subsection{Faktor yang Berpengaruh dalam Pengembangan Potensi Pariwisata Pantai Kuri Caddi}

Berdasarkan hasil analisis Chi Kuadrat dapat disimpulkan bahwa faktor yang berpengaruh dalam Pengembangan Potensi Pariwisata Pantai Kuri Caddi Desa Nisombalia Kabupaten Maros, yaitu :

a. Aspek Daya Tarik Wisata, dapat dilihat bahwa persepsi dalam pengembangan potensi Pariwisata Pantai Kuri Caddi menurut uji Chi Kuadrat berpengaruh terhadap aspek Daya Tarik wisata. Maka selanjutnya dilakukan uji kontingensi dimana hasilnya yaitu pengaruh lemah.

b. Aspek Sarana Penunjang Wisata, dapat dilihat bahwa persepsi dalam pengembangan potensi Pariwisata Pantai Kuri Caddi menurut uji Chi Kuadrat tidak berpengaruh terhadap aspek sarana penunjang wisata. Maka selanjutnya dilakukan uji kontingensi dimana hasilnya yaitu pengaruh sangat lemah.

c. Aspek Keamanan dan Kenyamanan di lokasi wisata, dapat dilihat bahwa persepsi dalam pengembangan potensi Pariwisata Pantai Kuri Caddi menurut uji Chi Kuadrat berpengaruh terhadap aspek keamanan dan kenyamanan di lokasi wisata. Maka selanjutnya dilakukan uji kontingensi dimana hasilnya yaitu pengaruh lemah.

d. Aspek Informasi dan Promosi Wisata, dapat dilihat bahwa persepsi dalam pengembangan potensi Pariwisata Pantai Kuri Caddi menurut uji Chi Kuadrat tidak berpengaruh terhadap aspek informasi dan promosi wisata. Maka selanjutnya dilakukan uji kontingensi dimana hasilnya yaitu pengaruh sangat lemah.

e. Aspek Aksesibilitas, dapat dilihat bahwa persepsi dalam pengembangan potensi Pariwisata Pantai Kuri Caddi menurut uji Chi Kuadrat tidak berpengaruh terhadap aspek aksesibilitas wisata. Maka selanjutnya dilakukan uji kontingensi dimana hasilnya yaitu pengaruh sangat lemah.

f. Aspek Peluang Kerja di lokasi wisata, dapat dilihat bahwa persepsi dalam pengembangan potensi Pariwisata Pantai Kuri Caddi menurut uji Chi Kuadrat berpengaruh terhadap aspek peluang kerja di lokasi wisata. Maka selanjutnya dilakukan uji kontingensi dimana hasilnya yaitu pengaruh lemah.

g. Aspek Pendapatan di lokasi wisata, dapat dilihat bahwa persepsi dalam pengembangan potensi Pariwisata Pantai Kuri Caddi menurut uji Chi Kuadrat berpengaruh terhadap aspek pendapatan di lokasi wisata. Maka selanjutnya dilakukan uji kontingensi dimana hasilnya yaitu pengaruh lemah.

Dari hasil analisis dapat disimpulkan bahwa faktor yang berpengaruh dalam pengembangan potensi Pariwisata Pantai Kuri Caddi yaitu Aspek Daya Tarik Wisata, Aspek Keamanan dan Kenyamanan, Aspek Peluang 
Kerja, dan Aspek Pendapatan. Sedangkan untuk Aspek Sarana Penunjang Wisata, Aspek Informasi dan Promosi dan Aspek Aksesibilitas tidak berpengaruh dalam pengembangan potensi Pariwisata Pantai Kuri Caddi.)

\subsection{Analisis SWOT}

Analisis SWOT (Strenghts, Weaknes, Opportunities, Threads) digunakan dalam strategi Pengembangan Potensi Pariwisata Pantai Kuri Caddi. Hasil yang diperoleh berdasarkan analisis SWOT adalah sebagai berikut:

Tabel 10. Matriks SWOT

\section{Kekuatan (S)}

1. Daya tarik wisata alam dengan pemandangan pantai dan kawasan hutan mangrove yang indah

2. Keberadaan wisata Pantai Kuri Caddi sangat didukung oleh masyarakat sehingga wisatawan merasa aman dan nyaman

3. Wisata Pantai Kuri Caddi membuka lapangan kerja baru bagi masyarakat lokal

4. Keberadaan wisata Pantai Kuri Caddi dapat meningkatkan PAD dan masyarakat lokal

\section{Peluang (O)}

1. Wisata pantai Kuri Caddi tercantum dalam Perda Kabupaten Maros nomor 2 tahun 2014, tentang penyelenggaraan kepariwisataan.

2. Pengembangan pariwisata berdasarkan Rencana Induk Pembangunan Kepariwisataan Daerah.

3. Kesiapan investor dalam mengembangkan wisata Pantai Kuri Caddi.

\section{Strategi S-O (Aggresive Strategies)}

1. Memanfaatkan daya tarik wisata Pantai Kuri Caddi dengan mengacu pada Perda Kabupaten Maros nomor 2 tahun 2014, tentang penyelenggaraan kepariwisataan.

2. Melibatkan masyarakat dalam mengembangkan wisata Pantai Kuri Caddi berdasarkan Rencana Induk Pengembangan Kepariwisataan Daerah.

3. Melibatkan investor dalam mengembangkan wisata Pantai Kuri Caddi, sehingga dapat meningkatkan PAD dan pendapatan masyarakat.

\section{Strategi S-T (Divensification Strategies)}

1. Menjaga kealamian daya tarik wisata alam Pantai Kuri Caddi dan hutan mangrove sebagai kawasan pariwisata daerah berwawasan lingkungan

2. Memanfaatkan PAD untuk pengembangan wisata Pantai Kuri Caddi dan diversifikasi produk wisata yang berbasis masyarakat lokal

3. Mengedukasi masyarakat untuk menjaga kebersihan lingkungan dan pembuatan papan pemberitahuan untuk menjaga lingkungan alami Pantai Kuri Cadi tidak tercemar.

\section{Kelemahan (W)}

1. Sarana penunjang di kawasan wisata Pantai Kuri Caddi masih minim

2. Informasi dan promosi dalam menarik wisatawan belum maksimal

3. Aksesibilitas menuju objek wisata Pantai Kuri Caddi masih sangat sulit

\section{Ancaman (T)}

1. Masalah tsunami atau gelombang tinggi pada musim tertentu

2. Persaingan wisata alam pantai baik dari dalam maupun luar kabupaten

3. Masyarakat/Pengunjung kurang sadar dalam menjaga kebersihan terutama membuang sampah plastik

\section{Strategi W-O (Turn Arround Strategies)}

1. Meningkatkan sarana dan prasarana pariwisata sesuai Perda Kabupaten Maros nomor 2 tahun 2014.

2. Meningkatkan aksesibilitas ke wisata Pantai Kuri Caddi dalam upaya pengembangan pariwisata berdasarkan Rencana Induk Pembangunan Kepariwisataan Daerah.

3. Meningkatkan peranan investor serta penggunaan teknologi informasi untuk melakukan promosi di media elektronik maupun secara langsung untuk menarik wisatawan berkunjung.

\section{Strategi W-T (Defensive Strategies)}

1. Meningkatkan sarana dan prasarana pariwisata untuk memitigasi bencana alam dan menjaga keberlanjutan wisata Pantai Kuri Caddi

2. Meningkatkan informasi dan promosi pariwisata daerah yang spesifik kepada keunggulan masing-masing daya tarik wisata pada media massa dan online.

3. Menyediakan prasarana persampahan secara optimal untuk menjaga kebersihan lingkungan Pantai Kuri Caddi. 
Tabel 11. Nilai Skor IFAS

\begin{tabular}{|c|c|c|c|c|}
\hline No. & \begin{tabular}{l|} 
Faktor Strategi Internsl \\
Kekuatan $(\mathbf{S})$
\end{tabular} & Bobot & $\begin{array}{l}\text { Rating (1- } \\
\text { 4) }\end{array}$ & Skor \\
\hline 1. & $\begin{array}{l}\text { Daya tarik wisata alam dengan pemandangan pantai dan } \\
\text { kawasan hutan mangrove yang indah }\end{array}$ & 0,3 & 4 & 1,2 \\
\hline 2. & $\begin{array}{l}\text { Keberadaan wisata Pantai Kuri Caddi sangat didukung } \\
\text { oleh masyarakat sehingga wisatawan merasa aman dan } \\
\text { nyaman }\end{array}$ & 0,2 & 3 & 0,6 \\
\hline 3. & $\begin{array}{l}\text { Wisata Pantai Kuri Caddi membuka lapangan kerja baru } \\
\text { bagi masyarakat local }\end{array}$ & 0,2 & 3 & 0,6 \\
\hline 4. & $\begin{array}{l}\text { Keberadaan wisata Pantai Kuri Caddi dapat meningkatkan } \\
\text { PAD dan masyarakat local }\end{array}$ & 0,2 & 3 & 0,6 \\
\hline & Total Skor & & & 3,0 \\
\hline & Kelemahan/Permasalahan (W) & Bobot & $\begin{array}{l}\text { Rating (4- } \\
\text { 1) }\end{array}$ & Skor \\
\hline 1. & $\begin{array}{l}\text { Sarana penunjang di kawasan wisata Pantai Kuri Caddi } \\
\text { masih minim }\end{array}$ & 0,2 & 2 & 0,4 \\
\hline 2. & $\begin{array}{l}\text { Informasi dan promosi dalam menarik wisatawan belum } \\
\text { maksimal }\end{array}$ & 0,2 & 2 & 0,4 \\
\hline 3. & $\begin{array}{l}\text { Aksesibilitas menuju wisata Pantai Kuri Caddi masih } \\
\text { sangat sulit }\end{array}$ & 0,3 & 1 & 0,3 \\
\hline \multicolumn{3}{|c|}{ Total Skor } & & 1,1 \\
\hline
\end{tabular}

Tabel 12. Nilai Skor EFAS

\begin{tabular}{|c|c|c|c|c|}
\hline \multirow{2}{*}{ No. } & Faktor Strategi Eksternal & & & \\
\hline & Peluang $(\mathrm{O})$ & Bobot & $\begin{array}{l}\text { Katung (1- } \\
\text { 4) }\end{array}$ & Skor \\
\hline \multirow[t]{2}{*}{1.} & Wisata Pantai Kuri Caddi tercantum dalam Perda & & & \\
\hline & $\begin{array}{l}\text { Kabupaten Maros nomor } 2 \text { tahun 2014, tentang } \\
\text { penyelenggaraan kepariwisataan. }\end{array}$ & 0,3 & 4 & 1,2 \\
\hline 2. & $\begin{array}{l}\text { Pengembangan pariwisata berdasarkan Rencana Induk } \\
\text { Pembangunan Kepariwisataan Daerah. }\end{array}$ & 0,3 & 3 & 0,9 \\
\hline \multirow[t]{3}{*}{3.} & $\begin{array}{l}\text { Kesiapan investor dalam mengembangkan wisata Pantai } \\
\text { Kuri Caddi. }\end{array}$ & 0,3 & 2 & 0,6 \\
\hline & Total Skor & & & 2,7 \\
\hline & Ancaman (T) & Bobot & $\begin{array}{l}\text { Rating (4- } \\
\text { 1) }\end{array}$ & Skor \\
\hline 1. & $\begin{array}{l}\text { Masalah tsunami atau gelombang tinggi pada musim } \\
\text { tertentu. }\end{array}$ & 0,3 & 2 & 0,6 \\
\hline 2. & $\begin{array}{l}\text { Persaingan wisata alam pantai baik dari dalam maupun } \\
\text { luar kabupaten. }\end{array}$ & 0,2 & 3 & 0,6 \\
\hline 3. & $\begin{array}{l}\text { Masyarakat/Pengunjung kurang sadar dalam menjaga } \\
\text { kebersihan terutama membuang sampah plastik. }\end{array}$ & 0,3 & 2 & 0,6 \\
\hline & Total Skor & & & 1,8 \\
\hline
\end{tabular}

Kesimpulan:
1. (IFAS) Hasil kekuatan - kelemahan $=3,0-1,1$
$=1,9$
2. (EFAS) Hasil peluang - ancaman $=2,7-1,8$
$=0,9$

\subsection{Strategi Pengembangan Potensi Pariwisata Pantai Kuri Caddi}

Adapun strategi yang digunakan untuk Strategi Pengembangan Potensi Pariwisata Pantai Kuri Caddi Desa Nisombalia Kabupaten Maros yaitu :

a. Memanfaatkan daya tarik wisata Pantai Kuri Caddi dengan mengacu pada Perda Kabupaten Maros nomor 2 Tahun 2014, tentang penyelenggaraan kepariwisataan.

b. Melibatkan masyarakat dalam mengembangkan wisata Pantai Kuri Caddi berdasarkan Rencana Induk Pengembangan Kepariwisataan Daerah

c. Melibatkan investor dalam mengembangkan wisata Pantai Kuri Caddi, sehingga dapat meningkatkan PAD dan pendapatan masyarakat lokal 


\section{KESIMPULAN}

Berdasarkan hasil penelitian yang telah dianalisis terkait Strategi Pengembangan Potensi Pantai Kuri Caddi Desa Nisombalia Kabupaten Maros, dapat disimpulkan bahwa faktor daya tarik, keamanan dan kenyamanan, peluang kerja, dan faktor pendapatan berpengaruh terhadap pengembangan wisata Pantai Kuri Caddi. Adapun sarana penunjang wisata, informasi dan promosi, serta aksesibilitas tidak berpengaruh terhadap pengembangan wisata Pantai Kuri Caddi. Strategi Pengembangan Potensi Pariwisata Pantai Kuri Caddi adalah memanfaatkan daya tarik wisata Pantai Kuri Caddi dengan mengacu pada Perda Kabupaten Maros nomor 2 Tahun 2014, tentang penyelenggaraan kepariwisataan; melibatkan masyarakat dalam mengembangkan wisata Pantai Kuri Caddi berdasarkan Rencana Induk Pengembangan Kepariwisataan Daerah serta melibatkan investor dalam mengembangkan wisata Pantai Kuri Caddi, sehingga dapat meningkatkan PAD dan pendapatan masyarakat lokal.

\section{DAFTAR PUSTAKA}

Badan Pusat Statistik (BPS) Kabupaten Maros. 2019. Kabupaten Maros Dalam Angka: Kabupaten Maros

Dian, W. (2011). Dampak Pariwisata terhadap Peluang Usaha dan Kerja Luar Pertanian Di Daerah Pesisir. Jurnal Transdisiplin Sosiologi, Komunikasi, dan Ekologi Manusia: 259-272.

Peraturan Daerah (PERDA) Nomor 02 Tahun 2014 Tentang Penyelenggaraan Kepariwisataan

Rina M \& Neni N (2016). Strategi Pengembangan Pariwisata dalam Rangka Peningkatan Pendapatan Asli

Daerah di Kabupaten Kuningan. Skripsi (diterbitkan). Kuningan: Universitas Kuningan.

Ritonga, J. (2005). Tipologi Pesan Persuasif. PT. Indeks: Jakarta

Sutrisno, H. (2000). Metodologi Research. Andi Yogyakarta: Yogyakarta

Suwantoro, G. (2004). Dasar - Dasar Pariwisata. Penerbit Andi Yogyakarta: Yogyakarta

Yoeti, H.A. (2008). Perencanaan Pengembangan Pariwisata. PT. Pradnya Paramita: Jakarta 